\title{
The Influence of Activity Credit Income Type to Total Interest Income
}

\author{
Sri Suartini, Dian Hakip Nurdiansyah \\ Faculty Economic and Business \\ Universitas Singaperbangsa \\ Karawang \\ Dian.hakipnurdiansyah@staff.unsika.ac.id
}

\begin{abstract}
Bank as a business institution that real life cannot escape the problem or financial institution that provides financial resources in the form of the loan. Based on the above description, the author interested in doing research on issues of interest income of banks that were examined aspects of the credit activities. Purpose of this research is to find out the influence of three credit activity to interest income. Methodology research is using a clasicc asumption and multiple regression test. As for the results of research can be concluded that Consumer credit is the first whose more affected to interest income. This can be seen on the $t$ count value of consumer credit for $t$ table $0.310<2.101$. The second affected is Working capital loans affected to interest income. This can be seen on $t$ values loans for $0.389<2.101$. Third it can be seen in the $t$-count value for investment loan amounting to 1,468 , while the $t$ table is 1.468. Fourth Variable of three credit activity together have a same effect on interest income and the three variables can be used to predict the increasing interest income.
\end{abstract}

\section{Keywords: Bank, activity credit, interest income}

\section{INTRODUCTION}

Bank in the operations collects funds from the public and distributes it back in a variety of alternative investments, in relation to the function of these fund collection and distribution, bank is often called an institution of trust. In line with the business characteristics, bank is a business segment whose activities are regulated by the government. The sector regulation done strictly by the monetary entrepreneur to the banking activities cannot be separated from its role in conducting monetary policy. Bank can influence the amount of money in circulation which is one of the objectives of regulations by monetary entrepreneur using various monetary policy tools [1]

In this case, bank is one of the financial institutions to engage in the provision of financial services to the public, in addition to other financial institutions such as insurance companies, pension funds, factoring and many more. Based on the Law of the Republic of Indonesia No. 7 of 1992 concerning Banking dated March 25, 1992 as amended by Law No. 10 of 1998.
Many authors have done research studies on credit activity influenced, Ijun Zou Reported that the findings reveal that credit risk management does have positive effects on profitability of commercial banks. Between the two proxies of credit risk management, NPLR has a significant effect on the both ROE and ROA while CAR has an insignificant effect on both ROE and ROA. However, from 2007 to 2012, the relationships between all the proxies are not stable but fluctuating [2].

Bank is a financial intermediary institutions that collects funds from the public in the form of savings as a source of bank funds and then distributes it back to the public in need in the form of credit, however, in distributing the funds back to the public, bank should not solely pursue high profits for the owners of the bank, but these activities must be in compliance directed to improve standards of living of the public, then in accordance with the second definition, the function of banks, other than as financial intermediaries, also provides the service in payment traffic, except Rural Bank (BPR) which is not allowed to perform activities in accordance with the third definition. The service activity in payment traffic is a difference in principle between the commercial banks and rural banks. For instance, commercial banks hold deposits, bundling them together as loans, operating payments mechanism, etc.

\section{LITERATURE}

Bank as a business institution that real life cannot escape the problem. Especially when associated with roles that carried the banking institutions in the context of an economic activity. Undeniably, in the dynamics of an economy, the existence of the banking sector has a vital role and strategic. Besides, Tabari, Ahmadi and Emami have 3 mentioned "the safety of banking system is depending on the profitability and capital adequacy of banks. Profitability is a parameter which shows management approach and competitive position of bank in market-based banking. This parameter helps the banks to tolerate some level of risk and support them against shortterm problems." The profitability of banks is influenced by different factors including management, size, location and time according to a study conducted. And it is of great interest to see how the profitability is affected by the risks faced by 
commercial banks. There have been lots of researchers devoted into this topic. For example, exists a positive relationship between liquidity and profitability of banks in 12 European, Northern American and Australian countries while the two variables are negatively related. Berger in 1995 in his empirical study surprisingly reported that for U.S. [3].

Another variable used is some studies is the scale of regulation in several banking sectors. Christos in his research find that operating costs and loan losses decrease sharply after states permit statewide branching and, to a lesser extent, interstate banking. The improvements following branching deregulation appear to occur because better banks grow at the expense of their less efficient rivals. External determinants of bank profitability are concerned with those factors which are not influenced by specific bank ${ }^{\text {ee }}$ s decisions and policies, but by events outside the influence of the bank. Several external determinants are included separately in the performance examination to isolate their influence from that of bank structure so the impact of the formers on profitability may be more clearly discerned [4]

In conducting this research, the research method used by the author is using associative and quantitative method, which is to analyze the influence of consumer loan, working capital loan, and investment loan to the interest income.

\section{DATA COLLECTION TECHNIQUE}

Data collected in this study is time-series or periodical data. The observed time period is 8 years, ie from 2007 to 2014 . Seeing from its source, the data collected can be categorized as internal and external secondary data. [5] Internal secondary data is data obtained from banks studied, while the external secondary data is data obtained from institutions outside the bank studied.

\section{METHODOLOGY RESEARCH}

After all the data is collected both interviews and data report collection required, then successively analyze and discuss the influence of the type of credit to the interest income. The analysis used is as follows:

\section{Classical Assumption Test}

The regression model obtained from ordinary least squares method is regression model that generates linear beat unbias estimator. [6]

\section{Autocorrelation}

The first deviation is the presence of autocorrelation namely correlation between sample members sorted through time lag, this deviation is usually appears on observations using time series data.

\section{Multicolinearity Test}

The second deviation is the presence of multicollinearity in the regression model.

\section{Heteroscedasticity}

The third deviaton is the presence of heteroskidastity in the regression model, namely the variance of variables in the constant model, i.e the estimator which is obtained inefficient, both in small and large sample, although the estimator obtained describes unbias population

\section{Multiple Regression Test}

\section{Multiple Correlation Analysis}

To determine the correlation between consumer loan, working capital loan and investment loan to the interest income, we use the formulation as follows [7] :

$$
R_{y x 1 x 2}=\sqrt{\frac{r_{y x 1}^{2}+r_{y x 2}^{2}-2 r_{y x 1} r_{y x 2} r_{x 1 x 2}}{1-r_{x 1 x 2}^{2}}}
$$

$R_{y x 1 x_{2}}=$ correlation between variable $\mathrm{X}_{1, .} \mathrm{X}_{2}, \mathrm{X}_{2}$ with variables $\mathrm{Y}$

$$
\begin{array}{ll}
r_{\mathrm{yx} 1} & =\text { correlation between } X_{1} \text { with } Y \\
r_{\mathrm{y} x 2} & =\text { correlation between } X_{2} \text { with } Y \\
r_{\mathrm{y} x 3} & =\text { correlation between } X_{3} \text { with } Y \\
r_{x 1 \times 2 \times 2} & =\text { correlation between } X_{1} X_{2} \text { with } X_{2}
\end{array}
$$

\section{Coefficient of Determination}

To determine the contribution of consumer loan, working capital loan and investment loan to the interest income, we use the formulation as follows [8]::

$$
\mathrm{CD}=\mathrm{R}^{2}
$$

\section{Multiple Regression Analysis}

To determine whether there is influence of consumer loan, working capital loan and investment loan to the interest income, the formulation of multiple regression is used

$$
\mathrm{Y}^{*}=\mathrm{a}+\mathrm{b}_{1} \mathrm{X}_{1}+\mathrm{b}_{2} \mathrm{X}_{2}+\mathrm{b}_{3} \mathrm{X}_{3}
$$

where:

$\mathrm{Y}^{*} \quad=$ The dependent variable predicted (interest income)

a $\quad=$ Constanta

$\mathrm{b}_{1} \mathrm{X}_{1}=$ Coefficient of regression $\mathrm{X}_{1}$ (consumer loan)

$\mathrm{b}_{2} \mathrm{X}_{2}=$ Coefficient of regression $\mathrm{X}_{2}$ (working capital loan)

$b_{3} X_{3}=$ Coefficient of regression $X_{3}$ (investment loan)

Variable a is equal to the value of $\mathrm{Y}^{*}$, if $\mathrm{X}_{1} \mathrm{X}_{2}$ dan $\mathrm{X}_{3}$ is equal to 0 . Whereas $b_{1}$ is a constanta of $X_{1}$ and $b_{2}$ is a constanta of $\mathrm{X}_{2}$ as well as $\mathrm{b}_{3}$ is a constanta of $\mathrm{X}_{3}$

\section{Hypothesis Test}

$t$-distribution test

To test the effect of each independent variable on the dependent variable, we use the following criteria:

Type of Credit to the Interest Income 
Ho: type of credit has no effect on interest income.

Ha: type of credit affects the interest income.

Decision-making criteria of t-count and t-table:

If $\mathrm{t}$-count is < t-table, Ho is accepted, it means the type of credit has no effect on interest income.

If $\mathrm{t} t$-count is $>\mathrm{t}$-table Ho is rejected, it means the type of credit affects the interest income.

The criteria in decision-making of probability (significance) with $\alpha 0.05$ :

If the probability is $>\alpha 0.05$, Ho is accepted, it means the type of credit has no effect on interest income.

If the probability is $<\alpha 0.05$, Ho is rejected, it means the type of credit affects the interest income [9].

$$
t \text { hitung }=\frac{\bar{X}-v}{s / \sqrt{n}}
$$

Where:

$$
\begin{aligned}
X & =\text { The average of sample } \\
v & =\text { Population hypothesized } \\
\mathrm{s} & =\text { The standard deviation of sample } \\
\mathrm{n} & =\text { The number of sample }
\end{aligned}
$$

t-table formulation:

$$
\text { t-table }=(\alpha 0,05 / 2=0,025 ; \mathrm{df}) \text { with } \mathrm{df}(\mathrm{n}-2)
$$

\section{$f$-distribution test}

To test the effect of independent variable to dependent variable, we used the following criteria:

f-count and f-table tes:

Ho: consumer loan, working capital loan and investment loan have no effect on interest income.

Ha: consumer loan, working capital loan and investment loan affect the interest income.

If f-count is < f-table, Ho is accepted, it means consumer

\begin{tabular}{|c|c|c|c|}
\hline Variable & Indicator & $\begin{array}{c}\text { Measureme } \\
\text { nt Scale }\end{array}$ & Data source \\
\hline $\begin{array}{l}\text { Konsumtif } \\
\text { Credit } \\
\text { ( X1) }\end{array}$ & $\begin{array}{l}\text { Purchase Tools } \\
\text { Household: } \\
\text { a refrigerator, } \\
\text { a television, } \\
\text { a chair, a bed to } \\
\text { the car even for } \\
\text { home purchases }\end{array}$ & Ratio & $\begin{array}{l}\text { Annual Report } \\
\text { banks studied, } \\
\text { and interviews }\end{array}$ \\
\hline $\begin{array}{l}\text { Working capital } \\
\text { credit } \\
\text { ( X } 2 \text { ) }\end{array}$ & $\begin{array}{l}\text { The field of trade: } \\
\text { supplier credit, } \\
\text { credit } \\
\quad \text { exports, credit } \\
\text { shopping } \\
\text { For industry: } \\
\text { working capital } \\
\text { loans mill food an } \\
\text { tekstil } \\
\text { for field crops: } \\
\text { credit purchases } \\
\text { of fertilizer, } \\
\text { pesticide drugs. }\end{array}$ & Ratio & $\begin{array}{l}\text { Annual } \\
\text { banks } \\
\text { and interviews }\end{array}$ \\
\hline $\begin{array}{l}\text { Investaton } \\
\text { Credit } \\
\text { ( X 3) }\end{array}$ & $\begin{array}{l}\text { Purchase of land } \\
\text { for industrial, } \\
\text { mining, } \\
\text { plantations } \\
\text { - The purchase of } \\
\text { machine-m } \\
\text { transportation } \\
\text { equipment, } \\
\text { equipment } \\
\text { production } \\
\text { equipment. } \\
\text { - } \\
\text { establishment of } \\
\text { the } \\
\text { buildings, hotels, } \\
\text { hospitals, } \\
\text { warehouses } \\
\text { offices, shopping } \\
\text { project, } \\
- \text { planter plants } \\
\text { hard } \\
\text { plantations to } \\
\text { produce } \\
\text { economically }\end{array}$ & Ratio & $\begin{array}{l}\text { Annual Report } \\
\text { banks studied, } \\
\text { and interviews }\end{array}$ \\
\hline $\begin{array}{l}\text { Interest income } \\
(\mathrm{Y})\end{array}$ & $\begin{array}{l}\text { The entire income } \\
\text { the interest paid }\end{array}$ & Ratio & $\begin{array}{l}\text { Annual Report } \\
\text { banks studied }\end{array}$ \\
\hline
\end{tabular}
loan, working capital loan and investment loan have no effect on interest income.

\section{VARIABLE CONDITIONS RESEARCH AND SCIENTIFIC RESEARCH REPORT}

TABLE 3.2 VARIABLE OPERATIONALITATION RESEARCH

Source: [10]

- Regression analysis

The data were analyzed using multiple linear regression model (multiple regression analysis) on the basis provided for the dependent variable ie interest income (Y) and independent 
variables, namely Credit Consumer (X1), Working Capital Loan (X2) and investment credit (X3).

The use of this model to test the effect of three independent variables with each of the dependent variable of interest income, both individually (partial) and overall (simultaneously)

TABLE 4.1 CONSUMER LOANS, WORKING CAPITAL LOAN, INVESTMENT CREDIT AND INTEREST INCOME (IN MILLION RUPIAH)

\begin{tabular}{|c|c|c|c|c|c|}
\hline year & Periode & $\begin{array}{c}\text { Konsumtif } \\
\text { Credit }\end{array}$ & $\begin{array}{c}\text { Credit } \\
\text { Working } \\
\text { capital }\end{array}$ & $\begin{array}{c}\text { Credit } \\
\text { Investatio } \\
\mathbf{n}\end{array}$ & $\begin{array}{l}\text { Interest } \\
\text { income }\end{array}$ \\
\hline \multirow{4}{*}{2007} & Quarterly I & 13.639 & 464.154 & 67.154 & 88.959 \\
\hline & Quarterly II & 280.664 & 612.383 & 234.890 & 203.640 \\
\hline & Quarterly III & 800.133 & 731.022 & 384.657 & 385.651 \\
\hline & Quarterly IV & 1.543 .090 & 1.280 .595 & 628.237 & 597.623 \\
\hline \multirow[t]{4}{*}{2008} & Quarterly I & 1.720 .794 & 1.218 .751 & 681.237 & 314.898 \\
\hline & Quarterly II & 1.999 .507 & 1.592 .064 & 854.195 & 658.934 \\
\hline & Quarterly III & 2.657 .557 & 1.664 .584 & 908.935 & $\begin{array}{l}1.077 .07 \\
8\end{array}$ \\
\hline & Quarterly IV & 2.748 .330 & 1.587 .728 & 908.333 & $\begin{array}{l}1.576 .33 \\
0\end{array}$ \\
\hline \multirow[t]{4}{*}{2009} & Quarterly I & 2.799 .901 & 1.119 .961 & 746.640 & 523.829 \\
\hline & Quarterly II & 2.852 .903 & 1.215 .992 & 607.996 & $\begin{array}{l}1.014 .08 \\
7\end{array}$ \\
\hline & Quarterly III & 3.187 .857 & 1.282 .175 & 793.686 & $\begin{array}{l}1.468 .28 \\
2\end{array}$ \\
\hline & Quarterly IV & 3.500 .019 & 1.471 .933 & 759.903 & $\begin{array}{l}1.918 .97 \\
6\end{array}$ \\
\hline \multirow[t]{4}{*}{2010} & Quarterly I & 3.267 .115 & 1.397 .185 & 616.398 & 432.653 \\
\hline & Quarterly II & 3.028 .831 & 1.113 .879 & 695.104 & 828.902 \\
\hline & Quarterly III & 3.198 .194 & 1.217 .178 & 746.173 & $\begin{array}{l}1.184 .02 \\
8\end{array}$ \\
\hline & Quarterly IV & 3.565 .206 & 1.579 .660 & 924.492 & $\begin{array}{l}1.547 .50 \\
4\end{array}$ \\
\hline \multirow[t]{4}{*}{2011} & Quarterly I & 3.647 .243 & 1.526 .047 & 760.104 & 374.566 \\
\hline & Quarterly II & 4.029 .546 & 1.661 .864 & 749.663 & 754.295 \\
\hline & Quarterly III & 4.665 .360 & 1.515 .182 & 705.505 & $\begin{array}{l}1.196 .37 \\
4\end{array}$ \\
\hline & Quarterly IV & 4.917 .656 & 1.315 .391 & 655.102 & $\begin{array}{l}1.650 .04 \\
0\end{array}$ \\
\hline 2012 & Quarterly I & 4.649 .845 & 1.588 .900 & 755.066 & 450.830 \\
\hline
\end{tabular}

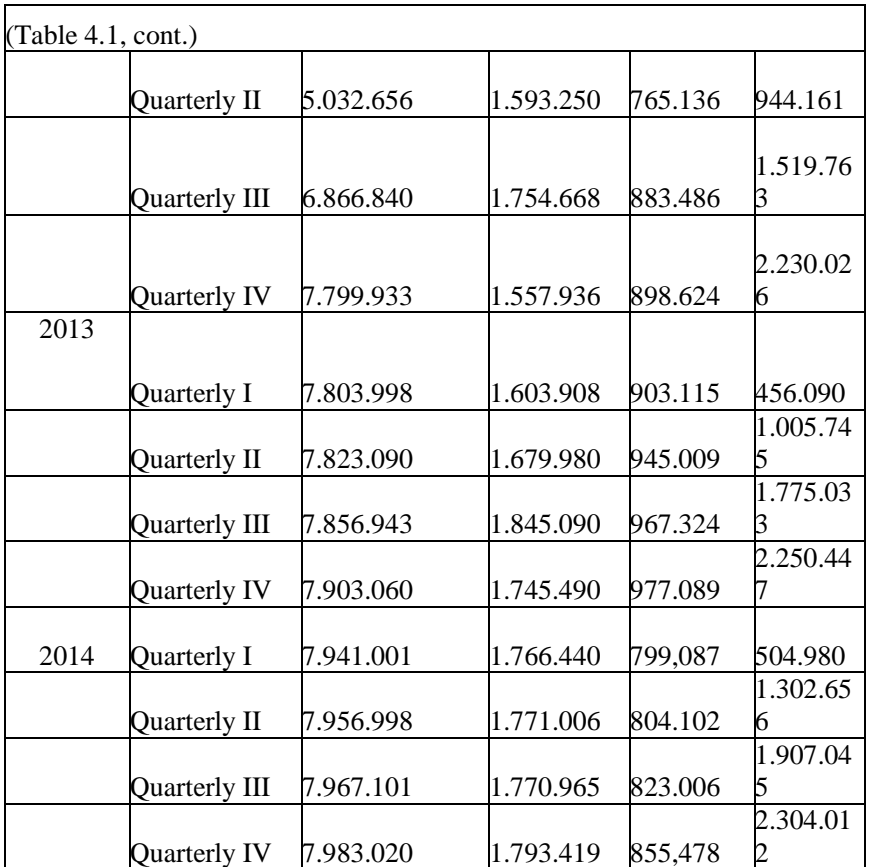

Source: Data processing SPPS, 2014

- Explanation :

a) The position of loan at the end of the first quarter of 2007 was amounted to 544,947 million with total interest income amounted to 88,959 million, while at the end of 2007 the loans increased to 3,451,922 million or approximately an increase of $533.44 \%$, then for the interest income at the end of 2007 became 597,623 million, which increased by $571.80 \%$ or 508,664 million. The percentage of increase in loans is comparable to the percentage of increase in loan income due to the position of these loans is in a good state.

b) The position of loan at the end of 2008 was amounted to 5,244,391 million from the end of 2007 amounted to $3,451,922$ million, which increased approximately $51.93 \%$ or $1,792,469$ million, while the interest income increased to 1,576,330 million at the end of 2008 from the position at the end of 2000 amounted to 597,623 million or $263.77 \%$.

c) The position of loan at the end of 2009 was amounted to $5,731,855$ million, which increased by 487,464 million or $9.29 \%$ from the end of 2008 amounted to 5,244,391 million, while the loan interest income increased from the end of 2008 amounted to $1.576,330$ million to $1,918,976$ million or $21.74 \%$.

d) The position of loan at the end of 2010 was amounted to $6,069,358$ million which increased by 337,473 million from the end of 2009 amounted to 5,731,855 million, while loan interest income decreased from the end of 2009 amounted to $1,918,976$ million to $1,547,504$ million at end position 2010 or decreased by $19.36 \%$, a decrease in loan interest income was due to the growth of poor loans, arrears.

e) The position of loan at the end of 2011 was amounted to $6,888,149$ million which increased by 818,791 million from the end of 2010 amounted to $6,069,358$ million, with a 
percentage of $13.49 \%$, while the loan interest income increased from the end of 2010 amounted to 1,547,504 million to $1.650,040$ million or an increase of $6.63 \%$.

f) The position of loan at the end of 2012 was amounted to $10,256,493$ million increased by $3,368,344$ million from the end of 2011 amounted to $6,888,149$ million, while the loan interest income increased from the position in 2011 amounted to $1.650,040$ million to $2,230,026$ million or an increase of $26.01 \%$.

$g$ ) The position of loan at the end of 2013 was amounted to $10,625,639$ million which increased by 369,146 million from the end of 2012 amounted to 10,256,493 million, while loan interest income increased from the end of 2013 amounted to $2,250,447$ million, or an increase of $0.92 \%$.

$h$ ) The position of loan at the end of 2014 was amounted to $10,631,917$ million which increased by 375,424 million from the end of 2013 amounted to 10,625,639 million, while loan interest income increased from the end of 2014 amounted to 53,565 million to $2,304,012$ million, or an increase of $2.38 \%$.

\section{A. Classical Assumption Test}

\section{1) Autocorrelation}

Important deviation of assumption in the regression is the autocorrelation, namely the correlation between members of a series of observations in a time series.[11]

This test is intended to test the correlation between confounding errors (ei) from one observation to another observation. Testing whether there is autocorrelation or not can be done using the Durbin-Watson Test (DW Test) where the value of DW table $\left(\mathrm{d}_{\mathrm{u}}\right.$ and $\left.\mathrm{d}_{\mathrm{L}}\right)$ is determined at the level of significance or $\alpha=5 \%$ and the degree of freedom or $\mathrm{df}=\mathrm{k}$ (the number of independent variables), number $=\mathrm{n}[12]$

TABLE 4.2 TEST AUTOCORRELATION

\begin{tabular}{|c|c|}
\hline Model & Tolerance \\
\hline X1 & 0,515 \\
\hline X2 & 0,208 \\
\hline X3 & 0,260 \\
\hline
\end{tabular}

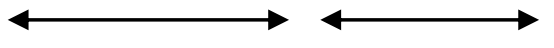

Refuse H0 result refuse $\mathrm{H} 1$

Autocorelation Autocorellation

Positif Negatif
The results of the Durbin Watson test value is shown as follows:

TABLE 4.3 MODEL SUMMARY

Model Summary

\begin{tabular}{|c|c|l|l|l|l|}
\hline $\begin{array}{c}\text { Mod } \\
\text { el }\end{array}$ & R & R Square & $\begin{array}{c}\text { Adjusted R } \\
\text { Square }\end{array}$ & $\begin{array}{c}\text { Std. Error of the } \\
\text { Estimate }\end{array}$ & Durbin-Watson \\
\hline 1 & $.596^{\mathrm{a}}$ & .356 & .286 & 547772.519 & 1.766 \\
\hline
\end{tabular}

Source: Results of processing SPSS 16.0 for windows, 2014

The test results of 1,766 whereas the Durbin Watson d table with a significance level of $0.05(\mathrm{k}=5)$ and the amount of data obtained as much as $32 \mathrm{~d}$ value table at 0.79 to 1.99 for the $\mathrm{dl}$ and du (Source: Statistical tables d-Durbin Watson) criteria if the value $\mathrm{d}>\mathrm{dL}$ and $\mathrm{n}<\mathrm{du}$ then there is no autocorrelation. Durbin Watson value based on the table of 1,766 greater than 0.79 and less than 1.99 it can be concluded that the above research $\mathrm{h}$ there is no autocorrelation in the regression model

\section{2) Multicolinearity}

Multicolinearity test should be done to the independent variables to ensure that the variable is free from multikolinear that a regression model is free from multicolinearity as follows:

\section{TABLE 4.4 COEFFICIENTS}

\section{Coefficients $^{\mathrm{a}}$}

\begin{tabular}{|c|c|c|c|c|c|c|c|}
\hline \multirow[b]{2}{*}{ Model } & \multicolumn{2}{|c|}{$\begin{array}{l}\text { Unstandardized } \\
\text { Coefficients }\end{array}$} & \multirow{2}{*}{ 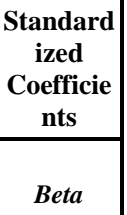 } & \multirow[b]{2}{*}{$\mathbf{t}$} & \multirow[b]{2}{*}{ Sig. } & \multicolumn{2}{|c|}{$\begin{array}{c}\text { Collinearity } \\
\text { Statistics }\end{array}$} \\
\hline & B & Std. Error & & & & $\begin{array}{c}\text { Toleranc } \\
e\end{array}$ & VIF \\
\hline (Constant) & $\begin{array}{l}- \\
221726.3 \\
13\end{array}$ & $\begin{array}{l}465234.1 \\
13\end{array}$ & & -.477 & .637 & & \\
\hline $\begin{array}{l}\text { Kredit } \\
\text { Konsumtif } \\
\text { (X1) }\end{array}$ & .017 & .053 & .066 & .310 & .759 & .515 & 1.941 \\
\hline $\begin{array}{l}\text { Kredit } \\
\text { Modal } \\
\text { Kerja (X2) }\end{array}$ & .243 & .625 & .129 & .389 & .701 & .208 & 4.810 \\
\hline $\begin{array}{l}\text { Kredit } \\
\text { Investasi } \\
\text { (X3) }\end{array}$ & 1.216 & .828 & .437 & 1.468 & .153 & .260 & 3.851 \\
\hline
\end{tabular}

a. Dependent Variable: Interest Income(Y)

Resource : result processing SPSS 16.0 for windows, 2014

- Have VIF value around 1

- Have TOLERANCE approaching 1

Based on the data processing results above, the research variable above, it can be obtained as follows: 


\section{c) Heteroscedasticity}

An important assumption of the classical linear is that the disruption arouse in the regression function is homoscedastic, i.e all disruption has the same variance [9]. One of the ways used to detect the heteroscedasticity is using the Glejser Test to examine the relationship between the absolute residual model (difference $\mathrm{Y}$ observations with $\mathrm{Y}$ predictions) with each independent variable.

Scatterplot

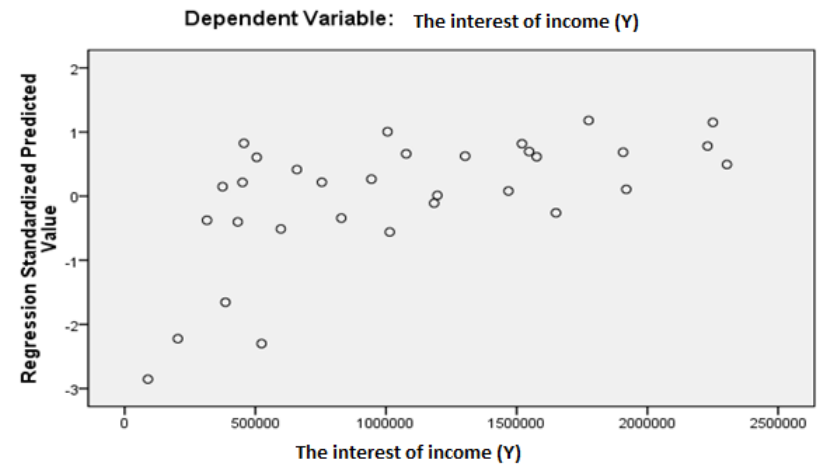

Fig. 2. Scatter Plot Dependent Variabel

Source: Processing results of SPSS 16.0 for Windows, 2014

If feasible regression model is used for prediction, then the data will be scattered around ( 0 on the $\mathrm{Y}$ axis) and do not form a particular pattern. [12] Based on the graph shows that the distribution of data is around 0 and does not appear any particular pattern on the distribution of the data. Thus we can conclude that regression model is eligible to predict the interest income. There is no symptom of heteroscedasticity in regression models. As well as that the regression model arranged above is a variable study that has no heteroscedasticity.

\section{Histogram}

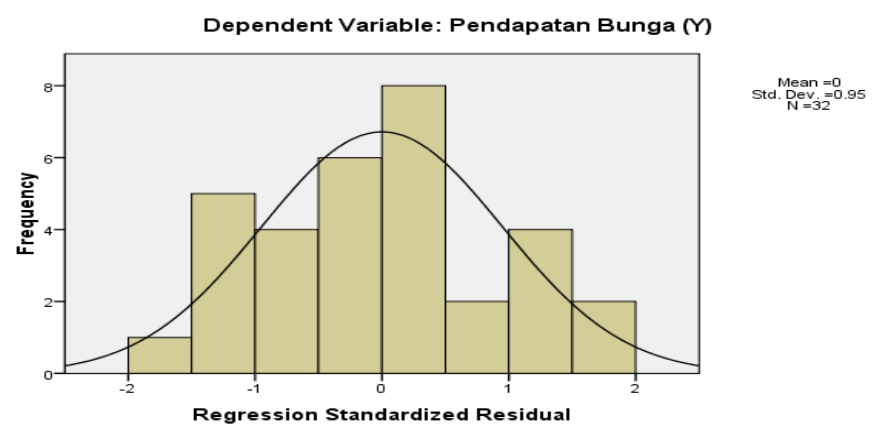

Fig. 3. Histrogram Plot Dependent Variabel

If feasible regression model is used for prediction, then the data will be scattered around 0 ( 0 on the $Y$ axis) and do not form a particular pattern [13]. Based on the graph shows that the distribution of data is around 0 , and does not appear any particular pattern on the distribution of the data. Thus we can conclude that regression model is eligible to predict interest income. There is no symptom of heteroscedasticity in regression models.

\section{d) Multiple Regression Test}

- Correlation

Based on the results of multiple regression processing using SPSS 16.00 for windows, the following table shows:

TABLE 4.5 CORRELATIONS

\begin{tabular}{|c|c|c|c|c|c|}
\hline & & $\begin{array}{c}\text { Kredit } \\
\text { Konsumt } \\
\text { if (X1) }\end{array}$ & $\begin{array}{c}\text { Kredit } \\
\text { Modal } \\
\text { Kerja } \\
\text { (X2) }\end{array}$ & $\begin{array}{c}\text { Kredti } \\
\text { Investasi } \\
\quad \text { (X3) }\end{array}$ & $\begin{array}{c}\text { Pendapa } \\
\text { tan } \\
\text { Bunga } \\
(Y)\end{array}$ \\
\hline \multirow[t]{3}{*}{$\begin{array}{l}\text { Kredit } \\
\text { Konsumtif (X1) }\end{array}$} & $\begin{array}{l}\text { Pearson } \\
\text { Correlation }\end{array}$ & 1 & $.696^{* *}$ & $.597^{* *}$ & $.417^{*}$ \\
\hline & Sig. (2-tailed) & & .000 & .000 & .018 \\
\hline & $\mathrm{N}$ & 32 & 32 & 32 & 32 \\
\hline \multirow[t]{3}{*}{$\begin{array}{l}\text { Kredit Modal } \\
\text { Kerja (X2) }\end{array}$} & $\begin{array}{l}\text { Pearson } \\
\text { Correlation }\end{array}$ & & 1 & & \\
\hline & Sig. (2-tailed) & .000 & & .000 & .001 \\
\hline & $\mathrm{N}$ & 32 & 32 & 32 & 32 \\
\hline \multirow[t]{3}{*}{$\begin{array}{l}\text { Kredit Investasi } \\
\text { (X3) }\end{array}$} & $\begin{array}{l}\text { Pearson } \\
\text { Correlation }\end{array}$ & & & 1 & \\
\hline & Sig. (2-tailed) & .000 & .000 & & .000 \\
\hline & $\mathrm{N}$ & 32 & 32 & 32 & 32 \\
\hline \multirow[t]{3}{*}{$\begin{array}{l}\text { Pendapatan } \\
\text { Bunga (Y) }\end{array}$} & $\begin{array}{l}\text { Pearson } \\
\text { Correlation }\end{array}$ & $.417^{*}$ & $.551^{* *}$ & $.588^{* *}$ & 1 \\
\hline & SSig. (2-tailed) & .018 & .001 & .000 & \\
\hline & $\mathrm{N}$ & 32 & 32 & 32 & 32 \\
\hline
\end{tabular}

c. $* *$. Correlation is significant at the 0.01 level (2-tailed).

d. *. Correlation is significant at the 0.05 level (2-tailed).

The table above shows the correlation coefficient for all variables. The correlation coefficient between consumer loan (X1) is 0.417 against interest income (Y) with a significance level 0. If $\mathrm{r}$ is 0.417 , it shows a quite strong positive correlation.

The correlation coefficient of working capital loan (X2) is 0.551 with a significance level of 0,000 , it shows a quite strong positive correlation.

The next correlation coefficient is investment credits (X3) of 0.588 with a significance level of 0.1 , it shows a quite strong positive correlation.

- Summary of Model

Summary of model can be presentes as follows: 


\section{TABLE 4.6 MODEL SUMMARY}

Model Summary ${ }^{b}$

\begin{tabular}{|c|c|c|c|c|c|}
\hline Model & R & R Square & $\begin{array}{c}\text { Adjusted R } \\
\text { Square }\end{array}$ & $\begin{array}{c}\text { Std. Error of } \\
\text { the Estimate }\end{array}$ & $\begin{array}{c}\text { Durbin- } \\
\text { Watson }\end{array}$ \\
\hline 1 & $.596^{\mathrm{a}}$ & .356 & .286 & 547772.519 & 1.766 \\
\hline
\end{tabular}

e. a. Predictors: (Constant), investment credits (X3), consumer loan (X1), working capital loan (X2)

f. b. Dependent Variable: Interest income (Y)

g. Source: Processing results of SPSS 16.0 for Windows, 2014

$R$ value shows a correlation between the three independent variables, ie consumer loan, working capital loan and investment loan amounting to 0.596 while the R Square (determination index) of 0.356 shows the contribution of consumer loan, working capital loan and investment loan to interest income by 35.60 percent, the remaining 64.40 percent is influenced by other factors that are not examined in this study. The standard error is $\mathbf{5 4 7 7 7 2 . 5 1 9}$

\section{TABLE 4.7 COEFFICIENTS}

\section{Coefficients $^{\mathrm{a}}$}

\begin{tabular}{|c|c|c|c|c|c|c|c|}
\hline \multirow[b]{2}{*}{ Model } & \multicolumn{2}{|c|}{$\begin{array}{l}\text { Unstandard } \\
\text { ized } \\
\text { Coefficients }\end{array}$} & \multirow{2}{*}{\begin{tabular}{|c|}
$\begin{array}{c}\text { Standard } \\
\text { ized } \\
\text { Coefficie } \\
\text { nts }\end{array}$ \\
Beta \\
\end{tabular}} & \multirow[b]{2}{*}{$\mathbf{T}$} & \multirow[b]{2}{*}{ Sig. } & \multirow{2}{*}{\begin{tabular}{|c|}
$\begin{array}{c}\text { Collinea } \\
\text { rity } \\
\text { Statistic } \\
\mathrm{s}\end{array}$ \\
$\begin{array}{c}\text { Toleranc } \\
e\end{array}$ \\
\end{tabular}} & \multirow[b]{2}{*}{ VIF } \\
\hline & $\boldsymbol{B}$ & $\begin{array}{c}\text { Std. } \\
\text { Error }\end{array}$ & & & & & \\
\hline $1 \quad$ (Constant) & $\begin{array}{l}2217 \\
26.31 \\
3\end{array}$ & $\begin{array}{l}4652 \\
34.11 \\
3\end{array}$ & & -.477 & .637 & & \\
\hline $\begin{array}{l}\text { Kredit } \\
\text { Konsumtif } \\
\text { (X1) }\end{array}$ & .017 & .053 & .066 & .310 & .759 & .515 & 1.941 \\
\hline $\begin{array}{l}\text { Kredit Modal } \\
\text { Kerja (X2) }\end{array}$ & .243 & .625 & .129 & .389 & .701 & .208 & 4.810 \\
\hline $\begin{array}{l}\text { Kredit Investasi } \\
\text { (X3) }\end{array}$ & 1.216 & .828 & .437 & 1.468 & .153 & .260 & 3.851 \\
\hline
\end{tabular}

\footnotetext{
h. Dependent Variable: Interest Income (Y)
}

${ }^{\text {i. }}$ Source: Processing results of SPSS 13.0 for Windows, 2014

From the calculation above, it can be made equation model as follows:

$\mathrm{Y}=-221726,313+0,017 \mathrm{X} 1+0,243 \mathrm{X} 2+1,216 \mathrm{X} 3$

Explanation :

\section{VALUE OF - 221726,313}

Is a constant value which indicates that if there is no increase in consumer loan, working capital loan and investment loan, the interest income is amounted to $-221,726.313$. In the first quarter, consumer loan occurred is 13,639 and interest income 88,959 meaning that if the company does not raise consumer loan, the interest income or consumer loan and constant interest income for the next year is amounted to $221,726.313$.

- Value of + 0,017 X1

is a regression coefficient which shows that any increase in consumer loan, there is an increase in interest income amounted to 0,017 . where the segment-based consumer loan has done very well and continuous from year to year.

\section{Value of $+0,243 \mathrm{X} 2$}

Is a regression coefficient which shows that any increase in working capital loan, then there will be an increase in interest income amounted to 0,243. The relationship between working capital loan with the interest income is positive (directly proportional relationship) meaning that working capital loan segment has been as expected.

\section{Value of $+1,216 \times 3$}

Is a regression coefficient which shows that any increase in investment loan, there is an increase in interest income of 1.216 , in which there are many chances to be increased in the investment loan.

t- count for investment loan is amounted to 0.310 while ttable $(\alpha 0.05,28-3=2.35)$ is $0.310<2.35$, thus Ho is accepted and $\mathrm{Ha}$ is rejected. It can be concluded that consumer loan has no effect on interest income.

This is due to the increased interest income of the next periods.

\section{e) t- count test of working capital loan}

Ho: there is no effect between working capital loan to the interest income

Ha: there is effect between working capital loan to the interest income

\section{If $\mathrm{t}$-count is $>\mathrm{t}$-table $(0.05 \alpha)$, Ho is rejected}

If $\mathrm{t}$-count is < t-table $(0.05 \alpha)$, Ho is accepted

t-count for working capital loan is 0.389 while t-table $(\alpha$ $0.05,28-3=2.35$ ) is $0.389<2,35$, hence Ho is accepted and $\mathrm{Ha}$ is rejected. It can be concluded that the working capital loan has no effect on interest income.

This is due to the increased interest income of the next periods

\section{f) $t$ - count test of investment loan}

Ho: there is no effect between investment loan to the interest income

Ha: there is effect between investment loan to the interest income 
If t-count is $>$ t-table $(0.05 \alpha)$, Ho is rejected

If $\mathrm{t}$-count is < t-table $(0.05 \alpha)$, Ho is accepted

$\mathrm{t}$-count for investment loan is 1.468 while $\mathrm{t}$-table $(\alpha 0.05$, $28-3=2.35)$ is $0,1,468<2,35$, hence Ho is accepted and $\mathrm{Ha}$ is rejected. It can be concluded that the investment loan has no effect on interest income.

This is due to the increased interest income of the next periods

\section{g) f-count test}

F testing (anova) is used to test the influence of the three independent variables to the dependent variable, this test can be done in two ways, namely by looking at the significance level by comparing the f-count and f-table.

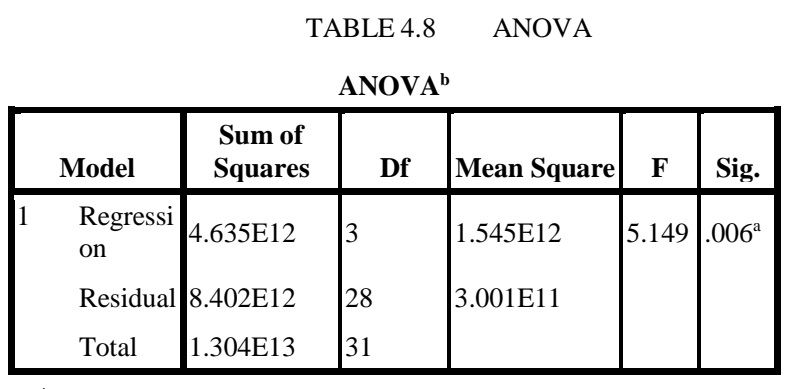

j. a. Predictors: (Constant), Kredit Investasi (X3), Kredit Konsumtif (X1), Kredit Modal

${ }^{k}$ b. Dependent Variable: Interest income (Y)

\section{h) Significance Level Testing}

Ho: there is no effect between consumer loan, working capital loan and investment loan to the interest income.

Ha: there is effect between consumer loan, working capital loan and investment loan to the interest income.

If the probability is $<0.05$, Ho is rejected

If the probability is $>0.05$, Ho is accepted

It can be seen that the level of significance (sig) in Annova table is 0.006 , so that the probability is $0.006>\alpha 0.05$, thus Ho is accepted and $\mathrm{Ha}$ is rejected. It can be concluded that consumer loan, working capital loan and investment loan jointly affect the interest income, the independent variables can be used to predict the variables in the period.

\section{CONCLUSION AND SUGGESTION}

\section{A. Conclusion}

Based on the results of research and the previous discussion, we can conclude as follows :

1. Consumer loan affects the interest income.

2. Working capital loan affects the interest income.

3. Investment loan affects the interest income.
4. The variables of consumer loan, working capital loan and investment loan jointly affect the interest income and the three variables can be used to predict the interest income

\section{B. Suggestion}

From the existing conclusion, it can be seen that the consumer loan, working capital loan and investment loan have a positive relationship to the interest income along with the development of Bank Mega credit growing, the company can increase Fee Based Income.

Based on the evaluation, the performance results of the credit is in line with the business development of Bank Mega. In order to increase credit distribution, one of the strategies that will be run in 2015 is expanding cooperation with development and property agents in creating a joint promotion.

- With competition in the banking on consumer loan, Bank Mega needs to expand its extent as well as increase the variety of products that fit the needs of the public.

- The companies need to further enhance the strategic implementation of various business ventures, one of which is a credit distribution program to micro, small and medium enterprises with the intended use as working capital.

- It should be developed concerning the granting of credit facilities of inventory, one of which is Mega Inventory Financing (MIF) as a subcontractor on receivables charged to the Business Partners who have contributed positively to the growth of Mega Bank credit.

- To balance the discontinuity in the sources of income as well as the risk which is too concentrated, Mega Bank should aggressively target a credit growth i.e a whole segment of consumer loan, working capital loan and investment loan and outside the credit segment.

\section{REFERENCES}

[1] Comptoller handbook. “ Investment Management Services” New York University. 2012.

[2] Zou Yijun. "The Impact of Credit Risk Management on Profitability of commrcial bank" UMEA Universitat. 2014. Pp 8-9

[3] The World Bank. (2014). Bank capital to assets ratio (\%) | Data $\mid$ Table. [online] Available at:

http://data.worldbank.org/indicator/FB.BNK.CAPA.ZS Accessed: 25 Mar 2014].

[4] Christos K. etc "The Determinants Of European Bank Profitability". Journal International Business \& Economics Research. 2005. Pp 75-76

[5] Cooper, Donald R. \& William C. Emory." Research Business methode". Jakarta: Erlangga. 1999

[6] Algifari. Ekonomi Mikro : Teori dan Kasus. Sekolah Tinggi Ilmu Ekonomi. Yogyakarta. 2003. Pp 73-74

[7] Sugiono Metode Penelitian Bisnis, Alfabeta CV, Bandung. 2004

[8] Sugiono Metode Penelitian Bisnis, Alfabeta CV, Bandung. 2004

[9] Lind, D.A., Mason, R.D., Marchal, W.G. "Analysis of Variance In", Basic Statistics. 3rd ed. McGraw-Hill. Singapore. 2000, pp 304-305.

[10] Cooper, Donald R. \& William C. Emory." Research Business methode". Jakarta: Erlangga. 1999

[11] Teguh Pudjo “Manajemen Perkeriditan”, Yogyakarta, 2001. 
[12] Alhusin, Syahri," Aplikasi Statistik Dengan SPSS.10 For Windows", Yogyakarta: Publisher Graha Ilmu, 2003. Pp 200

[13] Garujati, Damodar. “Ekonometrika”, Jakarta. Erlangga Publisher. 2001

[14] Garujati, Damodar. “Ekonometrika”, Jakarta. Erlangga Publisher. 2001, pp 201
[15] Santoso, Singgih."Metode Penelitian SPSS Versi 10; Statistical data processing professionally", Jakarta: PT Elex Media Computindo. 2001,pp. 254

[16] Santoso, Singgih."Metode Penelitian SPSS Versi 10; Statistical data processing professionally", Jakarta: PT Elex Media Computindo. 2001,pp. 254 